\title{
Contruction waste generation across construction project life-cycle
}

\author{
Mária Kozlovská \\ Technical University of Kosice \\ Faculty of Civil Engineering \\ Košice, Slovakia \\ maria.kozlovska@tuke.sk
}

\author{
Marcela Spišáková \\ Technical University of Kosice \\ Faculty of Civil Engineering \\ Košice, Slovakia \\ marcela.spisakova@tuke.sk
}

DOI 10.5592/otmcj.2013.1.5

Research paper

\section{Keywords}

Construction, Life cycle of construction, Construction and demolition waste (CDW), Waste disposal, Quantification of construction and demolition waste, Modern methods of construction (MMC)
THE CONSTRUCTION AND DEMOLITION WASTE (CDW), WHICH IS PRODUCED BY THE CONSTRUCTION PROCESS, PRESENTS 33\% OF THE TOTAL WASTE STREAM IN EUROPEAN UNION IN YEAR 2010 (EUROSTAT 2010). A CONSTRUCTION AND DEMOLITION WASTE IS GENERATED DURING WHOLE LIFE CYCLE OF CONSTRUCTION - DESIGN PHASE, REALIZATION PHASE, OCCUPATION PHASE AND DEMOLITION PHASE. On the other hand, the sustainable design of construction in the design phase presents possibility for the significantly reduce a volume of generated construction waste. In this phase, we are able to identify and quantify the volume and sort of construction waste. Based on this information, it is possible to determine the possibilities of construction waste disposal and the costs for its treatment.

This paper deals with proposal of options to reduce construction and demolition waste in the design phase as well as in the realization phase of constructions. The first part of paper describes possibilities of modern methods of construction use in the design phase of construction. The second part of paper describes the opportunities of cost reduction for the construction ways disposal. There are also analysed the foreign studies focused on the quantification of construction waste generation in the design and realization phase because the waste quantification provides a necessary tool for evaluating the true size of the wastes and hence making the adequate decisions for their minimization and sustainable management. The conclusion of paper involves a proposal of cost prediction for construction waste disposal through the most widely used of Slovak construction-economic software Cenkros Plus. 


\section{INTRODUCTION}

The increasing environmental impact from the construction becomes a serious problem that can cause significant damage, not only to ecosystems but also to the health and wellbeing of field workers and nearby residents of building sites (Li et al., 2009). Therefore, is necessary to approach and continuous effort within the industry in order to achieve the objectives sustainable construction and reducing of the environmental impacts of construction in each life cycle phase (construction project, realization, occupation, management and demolition) of buildings.

The authors Shen and Zhang (Shen et al., 1999) suggest that the impacts of construction activities on the environment include:

- competition for land with other activities such as agriculture;

$\checkmark$ adverse effect on the plots of land which are developed, and their environment, such as changing their ecological characteristics;

consumption of substantial volumes of physical resources, both renewable and non-renewable;

$\checkmark$ production of substantial volumes of wastes;

consumption of large amounts of energy during the processing of materials, the construction process and in the use of constructed items;

contribution to air pollution from the dust and substances, including some toxic ones, which are released during the production and transportation of materials, and in some construction operations; and

$>$ disruption of the lives of the people living in the vicinity of the project through traffic diversions, noise pollution and others.

The submitted paper deals with the production of construction waste in each life cycle phase, the possibilities of waste reduction and prediction of waste volume and costs for waste disposal already in design and realization phases.

\begin{tabular}{|c|c|c|}
\hline Country & $\begin{array}{l}\text { Total waste } \\
\text { [mil. tonnes] }\end{array}$ & $\begin{array}{l}\text { Construction and } \\
\text { demolition waste / } \\
\text { total waste [\%] }\end{array}$ \\
\hline EU-27 & 2570 & 33 \\
\hline Belgium & 44 & 7 \\
\hline Bulgaria & 166 & NA \\
\hline Czech Republic & 24 & 39 \\
\hline Denmark & 14 & 15 \\
\hline Germany & 364 & 53 \\
\hline Estonia & 19 & 2 \\
\hline Ireland & 20 & 8 \\
\hline Greece & 69 & 10 \\
\hline Spain & 138 & 28 \\
\hline France & 355 & 73 \\
\hline Italy & 179 & 39 \\
\hline Cyprus & 2 & 45 \\
\hline Latvia & 1 & 1 \\
\hline Lithuania & 6 & 6 \\
\hline Luxembourg & 10 & 84 \\
\hline Hungary & 16 & 20 \\
\hline Malta & 1 & 77 \\
\hline Netherlands & 119 & 66 \\
\hline Austria & 35 & 26 \\
\hline Poland & 159 & 13 \\
\hline Portugal & 38 & 29 \\
\hline Romania & 219 & NA \\
\hline Slovenia & 5 & 30 \\
\hline Slovakia & 11 & 17 \\
\hline Finland & 104 & 24 \\
\hline Sweden & 118 & 8 \\
\hline United Kingdom & 334 & 30 \\
\hline
\end{tabular}

Note: NA - no available

\section{Table 1 Volume of total generated waste and proportion of CDW in EU (Eurostat 2010)}

\section{Generation of construction waste}

Based on the recent statistics (Eurostat 2010), construction and demolition waste (CDW) present a third of total originated waste amount in the European Union (EU). It follows that the treatment and another reusing of CDW is a current subject within waste management not only in Slovakia, but also in other countries of EU.

The development in the field of construction production has a significant impact to production of waste 


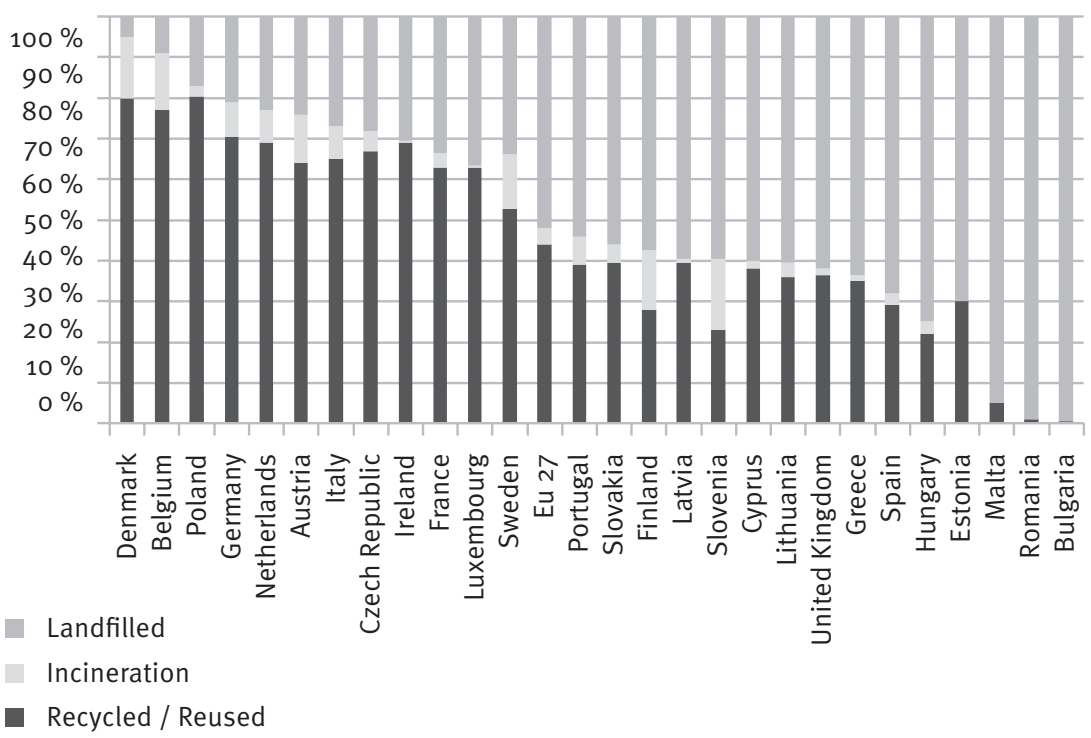

Figure 1 Construction and demolition waste disposal in EU (EEA - European environmental agency)

derived from the construction industry. Slovak construction industry achieves the best results and valuation in the years 2006-2008. On the other hand, we were the witnesses a significant decrease of total construction production in 2009 influenced by the global financial crisis.

The trend in the field of waste generation in the analysed period (2000 - 2009) has a decreasing tendency. In this period, construction and demolition waste presents $17,54 \%$ of the total waste production in Slovakia. Important is the fact, that the proportion of hazardous waste within CDW presents $1-5 \%$. Thus, CDW is suitable for reusing or recycling and does not require a special treatment and disposal. Table 1 illustrates a generation of CDW in Slovakia in the context of state in the selected countries.

Currently, the issue of waste disposal is interesting for the government as well as the public. The waste recovery - reusing and recycling is supported by government in accordance the environmental policy of EU. Although, almost all financial funds are directed to supporting of the separation, reusing and recycling of waste, the landfilling presents a main form of waste disposal. The figure 1 describes different approaches of construction and demolition waste recycling in many EU countries.

\section{Generation of construction} waste in the context of life cycle of construction

- The construction does not present only benefit for environment and society, but has a several negative influences, which are included in the life cycle of construction. The life cycle of construction consists of four basic phases:

- design of construction,

- realization of construction,

- occupation of construction,

- demolition of construction (figure 2). One of the elements negatively affected the environment is a waste origin. On the other hand, we are able to influence the amount and type of construction waste in each phases of this life cycle.

One way of reducing construction waste in first phase - design of construction - presents the sustainable design of construction through Building Information Modelling (BIM). This suitable tool allows a modelling by multidisciplinary superimposed information within one model. It creates an opportunity for sustainability measures to be incorporated early in the design process (Azhar et al., 2012). BIM can support the construction design in the following aspects of sustainable design what present the way of reduce to negative environmental impacts as well:

- building orientation (to select the best building orientation that results in minimum energy costs),

- building massing (to analyze building form and optimize the building envelope),

- energy modelling (to reduce energy needs and analyze renewable energy options such as solar energy),

- water harvesting (to reduce water needs in a building),

- sustainable materials (to reduce material needs, to use recycled materials and to use of new modern methods of construction),

> site and logistics management (to reduce waste and carbon footprints).

- As we can see, one of BIM use benefit presents a reduction of origin construction waste by sustainable materials.

The realization phase of construction is characterized by waste generation from basic, auxiliary, preparatory and transport building processes. In this phase, the construction waste is created by the realization of construction processes in the building site. The suitable way to waste reduction on site is the separating, disposal eventually the recycling of construction waste. The emphasis is on:

- increasing of disposal waste measure, mainly by waste reusing and in-site waste recycling,

- increasing of recycling measure with the aim to make the products with higher added value,

- minimization of total costs, which are needed on unit of recycled material production.

The phase occupation and management of construction is a producer of minimum amount of construction 


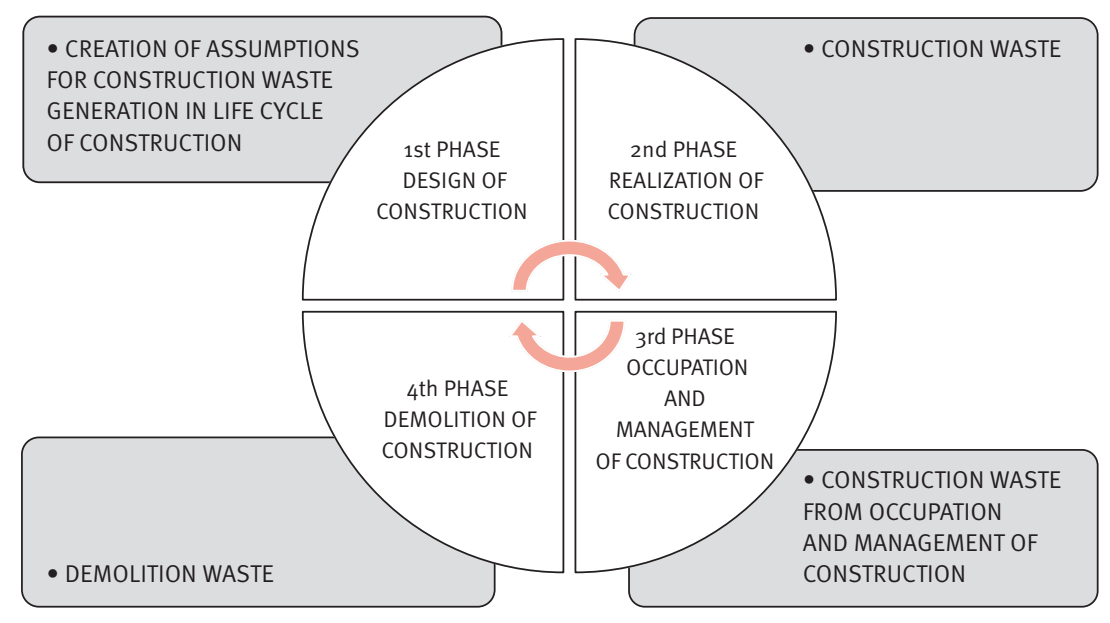

Figure 2 Construction and demolition waste generation in the life cycle phases of construction

waste. The primary assumption of this argument is the using and occupation of construction for particular purpose and using of the idea of facility management.

The last phase of life cycle presents the demolition of construction. The quality and composition of construction and demolition waste can largely influence the realization of demolition of building structure, construction or their parts. The choice of the optimal demolition technology always depends on the particular case. Consideration has to be given to the impact of the demolition on particular reconstructed structure, nearby objects and the surroundings (Makýš, 2000). The demolition works can be carried about in particular - manually, mechanized, explosive. Another possible approach to the demolition and destruction of structures or their parts is the deconstruction of buildings elements. The deconstruction of structures (dismantle of structure) allows the preservation of the building material (precast panels) for its further use (Šterba et al., 2012).

The most acceptable way of demolition work in term of the subsequent use of construction and demolition waste is the deconstruction of construction into the individual construction elements. On the other hand, we can say, that this method is used in our conditions at least, although the obtained components do not require major adaptations. In terms of the waste management would be appropriate to use the manual demolition, or mechanized demolition combined with manual, where already at the building site would be provide a primary pre-sorting of particular construction waste. On the other hand, this demolition is difficult and ultimately ineffective. The least suitable demolition method is the demolition through the explosive, what presents a complete destruction of structures parts that cannot be subsequently sorted to types of waste.

The part of each demolition technology has to be a careful separation of individual waste components in terms of its future use. It is clearly shown that the separation of particular types of waste already on the building site is far more effective and cheaper than in the recycling centre. During the demolition works is easier to separate the mineral debris from other materials, especially wood, plastics, tar cardboard and metals.

During the demolition works is important to emphasize:

> separation of contaminated materials from uncontaminated,

> separation of foreign materials from mineral debris intended to recycling. It is closely connected with the cre- ation of sorting logistics system already on the building site, where is providing the separation of these parts in the several separate containers. There are particular the metals, organic materials - the used wood, some minerals materials - stones, mortar, and other mainly hazardous waste - paints, asbestos.

> separation of inert mineral debris at least the basic types - brick rubble, concrete rubble, bitumen debris and excavated soil (Škopán, 2009).

\section{Reducing of construction waste through modern method of construction}

Modern methods of construction (MMC) primarily involves the manufacture of constructions in factories, with potential benefits such as faster construction, fewer housing defects, reductions in energy use and waste (Postnote, 2003) and offer significant potential to minimise construction waste (WRAP, 2009) and safety risks (Struková, 2009). Modern methods of construction have been shown to achieve a dramatic reduction in the waste generated on site. MMC is reasonably common in building construction but are less often used in civil engineering. For civil engineering projects, MMC can include use to pre-cast (pre-fabricated) components or preassembled structure. Prefabrication can be defined as a manufacturing process, generally taking place at a specialized facility, in which various materials are joined to form a component part of a final installation (Haas et al., 2000).

We can suggest the main advantages of MMC are economic, environmental and social (Postnote, 2009; Baldwin et al., 2009). The environmental benefits of MMC can be divided into these three main groups:

- energy savings - houses built using MMC typically require less energy to heat because of increased levels of insulation fitted in the walls and 
roof, and also less air leakage from the building.

cconstruction waste - the amount of waste produced using MMC is likely to be reduced because factory materials can be ordered to exact specifications, and there is a lower risk of on-site spoilage, e.g. through wet weather. However, there is little research confirming such reductions.

transport - building constructions in factories may reduce the total number of trips to a building site. This is of growing importance as more house building takes place on 'brownfield' sites in inner-city areas. Little detailed analysis has been conducted to date on transport benefits, but they are likely to vary considerably depending on the distance between the building site and the factory.

Modern methods of construction have been shown to achieve a dramatic reduction in the waste generated on site. MMC is reasonably common in building construction but is less often used in civil engineering.

During the processing of this paper have been analysed 4 selected studies intended in reduction of CDW by MMC and the comparison of conventional and modern method of construction (Jailoon, 2009; WRAP, 2007; Tam et al., 2007; Chen et al., 2010).

The authors of study (Tam et al., 2007) processed a research, in order to explore wastage reduction by adopting prefabrication, 30 construction projects adopting conventional construction and modern construction (prefabrication) have been measured. Although wastage levels may vary from different types or natures of project, the wastage levels are believed to be affected by the adoption of conventional in situ and modern (prefabrication) construction methods. A structured survey was conducted to measure the wastage level for the different construction methods. The average wastage level (in per cent) for various construction trades, namely, concreting, rebar fixing, bricklaying, drywall, plastering, screeding and tiling, are measured for the two groups of projects adopting conventional in situ trades and modern method (prefabrication) in table 2.

According to table 2, the average wastage level of the conventional construction method is much higher than that of prefabrication in the trades of concreting, rebar fixing, plastering and tiling. This result shows that the wast- age levels vary with different trades when prefabricated (modern) building components are adopted; therefore, the standardized designs of building can reduce the wastage levels effectively. The private housing projects generate the highest wastage levels especially for steel reinforcement, which may reflect from the non-standardized building structures resulting in different sizes of formwork, reinforcement, and brick/ block work that generate higher levels of material wastage.

\section{Opportunities of cost reduction for the construction waste disposal}

Within the processing of sustainable design of construction for realization phase of construction is realized a quantity takeoff of needed construction works and material. The takeoff presents the species, volume and cost evaluation of construction works and material in the budget. Based on this input, the constructor is able to specify the type, price and quantity of needed building material and construction works (Pospíchal et al., 2009). One way of reducing costs for waste disposal presents a prediction of these costs already in the phase of design and realization of construction.

\begin{tabular}{|c|c|c|c|}
\hline & \multicolumn{2}{|c|}{ Average wastage level in (\%) } & Percentage of waste reduction \\
\hline Trades & $\begin{array}{c}\text { Conventional method of } \\
\text { construction }\end{array}$ & $\begin{array}{c}\text { Modern method of } \\
\text { construction }\end{array}$ & MMC \\
\hline Concreting & CMC & 2 & 90 \\
\hline Rebar fixing & 20 & 2 & 92 \\
\hline Bricklaying & 25 & NA & NA \\
\hline Drywall & 15 & 5 & NA \\
\hline Plastering & NA & 0 & 100 \\
\hline Screeding & 23 & NA & NA \\
\hline Tiling & 25 & 7 & 74 \\
\hline
\end{tabular}

Note: NA - no available

Table 2 Wastage level between conventional and modern method of construction (Tam et al., 2007) 
Analysis of construction and demolition waste quantification studies

Currently, we are able to determine the volume of construction waste before the realization phase only by a not accurate estimate based on previous experience of constructor. In most cases, construction waste is simply estimated globally in the projects. The one of the main hindrances of accurate determination of waste volume is the lack of data, studies and the poor documentation of waste generation. Several foreign studies deal with the issue of CDW quantification.

\section{Study of University in Sevilla, Spain}

The author Llatas developed a model for quantifying construction waste according to the European waste list (Llatas, 2011). The model considers the construction project as the main source of waste because in this phase are created the technician designs, locates, describes, quantifies and specifies the different building elements that are required to construct a building. As a consequence of these decisions, the execution of the works and future demolition of the building will certainly involve the production of waste materials. That is, the types and quantities of waste generated in a work are the result of the changes experienced by the materials supplied to it and their packaging are introduced into the construction process. Broadly, the model estimates the types and volume of building materials and their packaging supplied to the work. This model develops three basic tools: the first tool is a systematic structure of the construction process in order to identify in the project the building/sitework elements and their materials and components. The second implementation is a waste classification system in order to obtain the list of waste coded according to the European waste list (EWL). And finally it provides the analytical expressions that estimate the amount of packaging waste, remains and soil. Seven types of waste can be distinguished - excavated earth, concrete, masonry blocks, mortar, aggregate, plaster mixture and tiles. Based on the information from quantity takeoff, the waste volume was determine through five factors (FP packaging waste factor, $\mathrm{FR}$ - remains factor, FS - soil factor, FC - conversion factor a $\mathrm{FI}$ - increased volume factor). Consequently, these wastes are classified according the EWL.

\section{Study of Univesity of Minho, Portugal}

Next study focused on the quantification of construction waste volume is developed by the University of Minho in Portugal by author Jalali. This methodology is based on the determination of a fairly accurate estimate of the amount and type of waste foreseen through the analysis of the project, construction processes and materials that will be used (Jalali, 2011). The schedule of the construction work is an essential tool, as it provides the timetable for waste generation and thus the required information on the logistics of the waste management for any given time span. The methodology involves the defining of: - Component Index $(\mathrm{Cl})$ - provides the information about volume of waste generated from each Construction Component (CC) which has a specific function in the building and is usually performed by a given professional on the site. It is a specific and independent part of the construction (e. g.: 1 $\mathrm{m} 2$ of concrete retaining wall $0.20 \mathrm{~m}$ thick, 1 m2 of ceiling, m2 of interior partition wall,...).

- Global Index (GI) - is based on the global data from similar construction types that provides the amount of waste per square meter of construction. The global data is gathered from previous construction works and registered on data files for particular construction;

The first step is to define the List of Construction Components relevant for waste quantification, where are characterized the materials, technical parameters and composition of construction waste per one unit of measure of particular CC. Subsequently, there is determined the most adequate waste disposal of particular CC. This List of CC is processing by least three measurements make for establishing a reliable data base.

The Global Index is a global presentation of data related to a specific construction such as specific type of construction, e.g. residential buildings, office buildings, hotels,.... The information is a general nature and uses the overall indicators generated from the building sites. This data file states the data for global waste production to be used in planning phase of the project. This GI provides information about construction type, the list of major tasks of project which indicating the quantities of each task in $\mathrm{m}_{2}, \mathrm{~m}_{3}$ or $\mathrm{kg}$ in the construction, list of generated waste on the site. Based on the total waste generated, the total area and volume of the building studied the management indicators are calculated. These indicators are used for quantification of wastes in similar buildings. Data from GI provides the necessary information about the volume, mass and type of the generated waste per square meter of building.

\section{Study of University of Malaya, Malaysia} The aim of study from University of Malaya in Malaysia is to establish benchmarks on construction waste generation rate at Klang Valley in Malaysia using appropriate waste quantification method (Masudi et al., 2010). This methodology is able to identify the waste volume in the realization phase of construction life cycle.

There are many factors that contribute to construction waste amount. The amount and type of CDW depends on: type of projects, size of the projects, activity performed and construction technology. For new building construction, there are defined two main 
types of waste - structure waste and finishing waste. For the purpose of this study, were selected nine construction projects in Klang Valley which mainly include residential and commercial buildings by a wide range of constructors employing conventional and modern (MMC - metal formwork system, precast concrete system) technologies. Wastage level and waste index approaches had been employed in this study as tools for quantifying waste and also for environmental assessment. As in other studies, there were defined types of waste that generated at significant amount, such as concrete, timber, reinforcement bars, finishing waste from tiling, screeding, and plastering are considered. Major data extracted in this study are: Gross Floor Area (GFA), material order quantities, material used quantities and construction debris disposal record. The main objective is to compare the total amount of debris and the percentage of total material quantities wasted during construction process according to type of building, size of project, construction system employed, contractors' policies and waste management practice, likely sources and causes of waste. In this research (Masudi et al., 2010) is describe the methodology for calculating of waste index (identifies the total volume of debris generated per GFA for each construction site) and waste level (estimates the quantity of wastage from total order quantities for various material).

The result can be concluded that type of building, design, and size of project, and site management are the main factors for construction waste amount as stated by previous studies. High-end buildings with complicated facades and design, regardless of the type of building, usually produce significantly higher amount of waste. This research does not prove the one of the MMC advantage - waste reduction. Two project were utilizing MMC did not have some correlation with waste amount.

\begin{tabular}{|c|l|l|c|c|}
\hline TV & Code & Description & UM & Volume \\
\hline M & 0821131000 & Water for industry and service & $\mathrm{m}^{3}$ & 0,12030 \\
\hline M & 5893293000 & Concrete C 25/30, Portland cement, 22 mm fraction & $\mathrm{m}^{3}$ & 1,01000 \\
\hline M & 6316521000 & Mat Rotaflex, size $20 \mathrm{~mm}, 20 \mathrm{ks} / \mathrm{m}^{3}$ & $\mathrm{~m}^{2}$ & 0,00551 \\
\hline W & 0821131000 & Water for industry and service & $\mathrm{m}^{3}$ & 0,01203 \\
\hline W & 5893293000 & Concrete C 25/30, Portland cement, 22mm fraction & $\mathrm{m}^{3}$ & 0,10100 \\
\hline W & 6316521000 & Mat Rotaflex, size $20 \mathrm{~mm}, 20 \mathrm{ks} / \mathrm{m}^{3}$ & $\mathrm{~m}^{2}$ & 0,00055 \\
\hline
\end{tabular}

Table 3 Completion of technological-organizational variant in Cenkros plus database

Though, projects utilizing MMC had relatively faster completion time. From company's management system point of view, it was found that there were no correlations between ISO14001-certified contractors with non-ISO14001certified contractors on waste minimization performance. Contractors which adopted proper Waste Management Plan (needed for ISO certificate) have to implement reuse and recycling program and better and more effective waste management.

\section{Proposal of construction and} demolition waste quantification in Slovakia

The submitted paper provides a system utility tool for prediction of volume waste in the phase of quantity takeoff processing. There are used the database constructively and economic software Cenkros Plus which is widely extended in Slovak construction environment. This software allows the determination of costs, volume and type of construction material, machinery and works and the costs of particular items.

The accurate prediction of volume and type origin construction waste during the construction process is suitable by the completion of technological - organizational variant (TOV) in the Cenkros Plus database (table 3 ). Figure 4 provides an output (in Slovak) from database Cenkros Plus - technological-organizational variant for concreting of foundation slabs.
There is necessary the TOV to supplemented with information about the volume and costs valuation of construction waste, which generated during the realization of particular process (table 3). We can use one of the known methods for CDW quantification. Obviously, the Cenkros Plus database is extensive. Given that, it is suitable to supplement the data about the construction waste only to selected items which produce the largest volume of construction wastes origin (Lallas, 2011; Jalali, 2011; Masudi et al., 2010):

$>$ excavated earth,

$>$ concrete,

$\checkmark$ masonry blocks,

$>$ mortar,

$\checkmark$ aggregate,

plaster mixture,

$>$ tiles.

The table 3 provides the example of completion of technological-organizational variant by the volumetric assessment of the generated waste during the realization of 1 unit of measure (UM) concreting of foundation slabs. The generated construction waste is marked by the symbol "W". Similarly, it is possible to process the cost valuation of construction waste. The appropriate decision-making process regarding the type of construction in the design phase can affect the generation of CDW. The selecting of the most suitable construction waste disposal can provide the opportunities of cost reduction for its. 


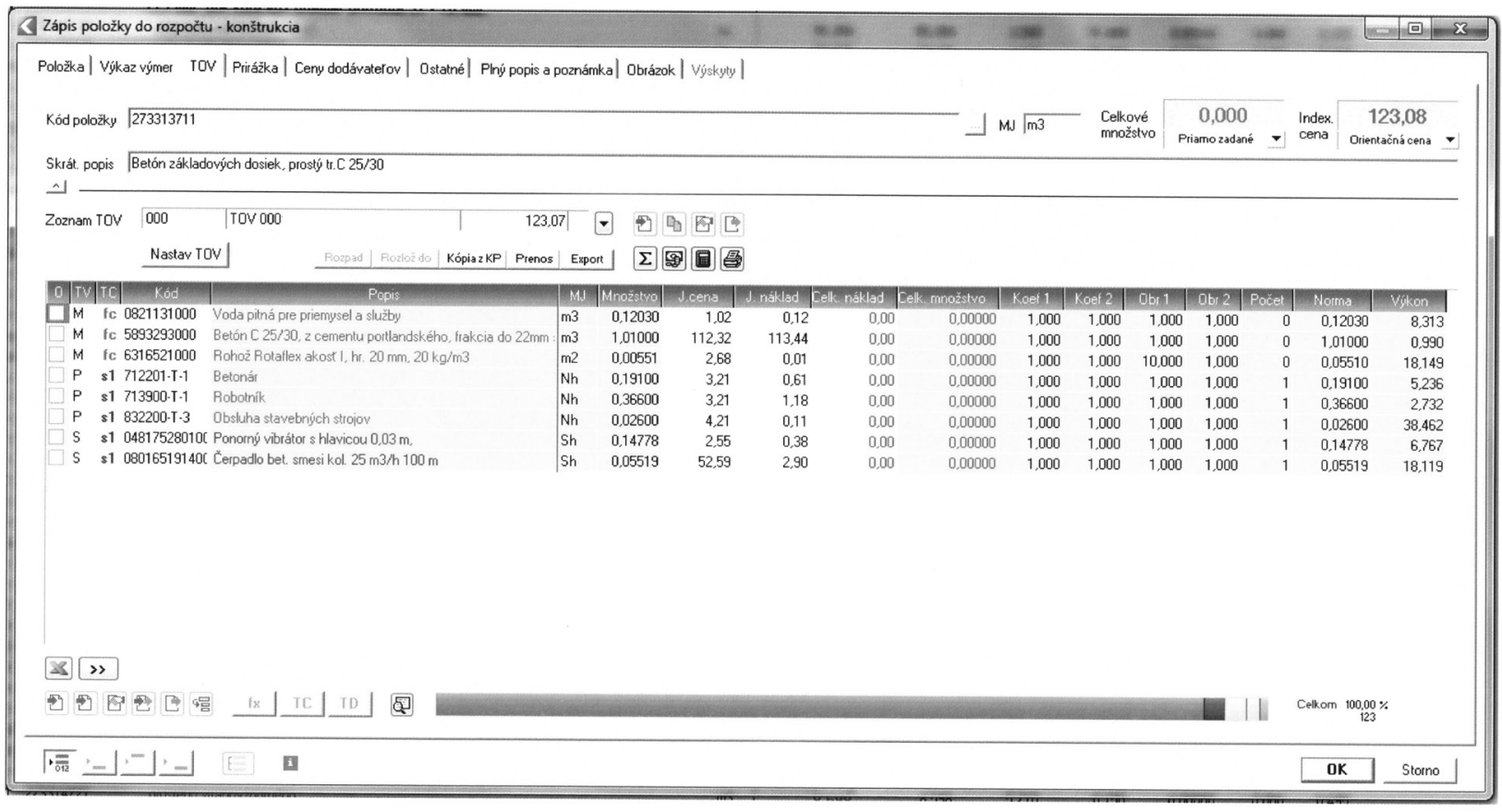

Figure 4 Technological-organizational variant for concreting of foundation slabs (in Slovak) (Kros)

\section{CONCLUSION}

The new EU challenge is to recover $70 \%$ by weight of CDW in 2020. One way to achieve this goal is to apply the sustainable design of construction. In terms of construction waste generation and management is the sustainable design also connected with the use of new innovative construction technologies which provide the reduction of construction waste then decreasing of the total cost for the waste disposal and the elimination of negative impact of construction to the environment. The modern method of construction presents one of the new environmental friendly technologies. The submitted paper dealt with the analysis and description of waste prevention by use of modern methods of construction, prediction of volume and costs characteristics in the design phase of construction and the opportunities of waste reduction in the all life cycles phases of construction. Estimation of construction waste amount is crucial for implementing waste minimization program. The paper also analysed the foreign researches involved the CDW quantification in different phases of construction life cycle. Consequently, there is proposed a way for determining of volume, type and cost of generated construction waste and its disposal through the specialized constructively and economic software Cenkros Plus. This method presents the systematic tools which is able to contribute to sustainable design of constructions.

\section{Acknowledgements}

This is article presents a partial result of projects VEGA No.1/0840/11 "Multidimensional approaches supporting integrated design and management of construction projects". 


\section{References}

Azhar, S., Brown, J. W., Sattineni, A. A. (2010), „A case study of building performance analyses using building information modelling", in 27th International symposium on Automation and Robotics in Construction, Slovakia, 2010, Tribun EU, Bratislava, pp. 2013-222.

Baldwin, A., Poon, Ch. S., Chen, L. Y., Austin. S., Wong, I. (2009), “Designing out waste in high-rise residential buildings: Analysis of precasting methods and traditional construction”, Renewable Energy, Vol. 34, pp 2067-2073

Current practices and future potential in modern methods of construction, Waste and resource programme, UK, 2007

Chen, Y., Okudan, G. E., Rilex, D. R. (2010) "Sustainable performance criteria for construction method selection in concrete buildings", Automation in construction, Vol. 19, pp 235-244

Database of company Kros, a. s., available at: www.kros.sk

Ellingerová, H. (2011) “Planning and management of construction budgetary costs", Organization, technology and management in construction journal, Vol. 3 , pp. 296-301

http://epp.eurostat.ec.europa.eu - waste website of European commission

http://www.eea.europa.eu/ - website of European Environmental Agency)

Haas, C. T., O־Connor, J. T., Tucker, R. L., Eickmann, J. A, Fagerlung, W. R. (2000) "Prefabrication and preassembly trends and effects on the construction workforce", working paper 14, The University of Texas at Austin, May 2000

Jaillon, L., Poon, C. S., Chiang, Y. H. (2009), "Quantifying the waste reduction potential of using prefabrication in building construction in Hong Kong”, Waste Management, Vol. 29, pp. 309-320

Jalali, S. (2011) "Quantification of construction waste amount”, available at: http://repositorium.sdum.uminho.pt/ bitstream/1822/9105/1/com25_9_50_A.pdf

Llatas, C. (2011) “A model for quantifying construction waste in projects according to the European waste list", Waste management, Vol. 31, pp. 1261-1276
Li, X., Zhu, Y., Zhang, Z. (2009), “An LCA-based environmental impact assessment model for construction processes", Building and Environment, Vol. 45, pp 766-775.

Makýš, P. (2000), Rekonstruction of buildings (Rekonštrukcie budov), Jaga, Bratislava, Slovakia

Masudi, A. F., Hassan, Ch. R. Ch., Mahmood, N. Z., Mokhtar, S. N., Sulaiman, N. M. (2011), "Construction waste quantification and benchmarking: A study in Klang Valley, Malaysia" Journal of Chemistry and Chemical Engineering, Vol. 5, pp. 909-916

Modern methods of house building, Postnote, UK, 2003

Pospíchal, V., Párová, M. (2010) “Determining of the construction waste quality and quantification before start of construction" in Realization and economics of construction, Slovakia, 2009, Košice - Dom techniky, pp. 131-135

Shen, L., Zhang, Z. (1999), “ISO 14 000: The process towards sustainable construction", working paper, RICS Research Foundation, pp $264-252$

Struková, Z. (2009),"Specific perception of safety risks in construction projects", in Innovative approach to modelling of intelligent construction elements in construction, Slovakia, 2009, VúSI, Košice, pp. 171-179

Škopán, M. (2009), “Technology for the efficient recycling of construction and demolition waste" (Technologie pro efektivni recyklaci stavebních a demolačních odpadu), Journal of Construction machinery and mechanization, Vol. 4, pp. 54-57

Šterba, M., Čech, D., Henková, S. (2012), "The use of building waste obtained during recycling together with organic material for revitalisation of panel housing estates" Journal of International Scientific Publications: Materials, Methods \& Technologies, Vol. 6, pp. 352-358

Tam, V. W. Y., Tam, C. M., Zeng, S. X., Ng, W. C. Y. (2007) "Towards adoption of prefabrication in construction" Building and Environment, Vol. 42, pp. 3642-3654 